\title{
OTDK-RA SZOCIALIZÁLÓ KONFERENCIA HALLGATÓKNAK - 2018
}

\author{
Mező Ferenc $(\mathrm{PhD})$
}

Mező Ferenc (2019): OTDK-ra szocializáló konferencia hallgatóknak - 2018. OxIPO - interdiszciplináris tudományos folyóirat, 2019/1, 105. doi: 10.35405/OXIPO.2019.1.105

2018.11.14.-én kísérleti jelleggel OTDK-ra szocializáló hallgatói konferencia megrendezésére került sor az Eszterházy Károly Egyetem Pedagógiai Karán megrendezésre.

A rendezvény célja az volt, hogy a (prezentációs, tanulás- és kutatásmódszertani felkészítésben is részesülő) hallgatók és középiskolások tapasztalatot szerezzenek az OTDK jellegü megmérettetésekkel kapcsolatban, annak érdekében, hogy motiváltabbak legyenek az OTDK-ba történő bekapcsolódásra.

A rendezvény a Nemzeti Tehetség Program által kiírt NTP-HHTDK-18-0061 azonosítószámú pályázat keretében valósult meg. A pályázat támogatója az Emberi Erőforrások Minisztériuma, lebonyolítója az Emberi Erőforrás Támogatáskezelő.

\section{EMBERI ERÖFORRÁSOK MINISZTÉRIUMA}

\section{$\approx \mid \begin{aligned} & \text { Nehzetség Program } \\ & \text { Tehet }\end{aligned}$}

A rendezvényen előadóként is résztvevő közel nyolcvan hallgató előzetesen tanulás módszertan orientációjú felkészítő kurzuson vett részt, melynek keretében a TDK-ról, a kutatás tervezésről, a dolgozat elkészítésének folyamatáról és a tudományos stílusú írásbeli és szóbeli prezentáció jellemzőiről szerezhettek ismereteket.

Az előadásokat egyénileg, illetve társszerzős formában adták elő a hallgatók. Témaválasztását tekintve a sokszínűség jellemezte az előadásokat: a múvészetektől a sporttudományon át a gazdaság-, táradalom-, bölcsészet- és természettudományos tárgyú prezentációkig terjedően halhattunk prezentációkat.Az előadásokból készült tanulmányok szerkesztett elektronikus kiadványban is megjelennek 2019. júniusában.

A rendezvény tanulsága, hogy a tudományos diákköri tevékenységre motiválni és egyben szocializálni célszerű a hallgatókat, mégpedig azért, mert sokuknál nemhogy nem alakult ki az a fajta előadói és szaktanulmány írói rutin, ami a TDK tevékenységre bátorítaná őket, hanem egyáltalán nem rendelkeznek efféle előzetes tapasztalattal.

A hasonló „házi” rendezvények biztonságos környezetben, a hallgatói támogatást garantáló módon oldhatja meg e problémát. Ezért a jövőben is folytatni célszerü hasonló rendezvények megvalósítását. 